\title{
PENINGKATAN KETERAMPILAN TATA BOGA MATERI PEMBUATAN BROWNIS KUKUS MELALUI MODEL PEMBELAJARAN EKSPLISIT
}

\author{
Mulya Sari \\ e-mail: ucimulyasari@yahoo.com \\ SLB Kembar Karya I Jakarta Timur
}

\begin{abstract}
Abstrak: Penelitian ini bertujuan untuk mengetahui peningkatan hasil belajar keterampilan tata boga materi pembuatan brownis kukus pada anak tunagrahita ringan dengan menggunakan model pembelajaran explicit instruction. Penelitian ini dilaksanakan pada peserta didik kelas XII SMALB-C Kembar Karya I, Jakarta Timur, dengan jumlah dua peserta didik pada bulan September hingga Oktober 2012. Penelitian ini menggunakan metode penelitian tindakan kelas (Classroom Action Research). Penelitian ini terdiri dari dua siklus, di mana setiap siklus terdiri dari 2 kali pertemuan. Analisis keberhasilan penelitian dilakukan secara individu, yaitu per aspek per anak karena perkembangan anak tunagrahita tidak dapat dibandingkan dengan anak lain melainkan perkembangan pada dirinya sendiri. Hasil penelitian menunjukkan adanya peningkatan hasil belajar keterampilan tata boga materi pembuatan brownis kukus pada anak tunagrahita ringan kelas XII SMALB-C Kembar Karya I yang dilakukan dengan menggunakan model pembelajaran eksplisit.
\end{abstract}

Kata-kata kunci: anak tunagrahita ringan, keterampilan tata boga, pembelajaran eksplisit.

\section{CULINARY SKILLS IMPROVEMENT OF THE MAKING STEAMED BROWNIES THROUGH EXPLICIT INSTRUCTION LEARNING MODEL}

Abstract: This study aimed at determining the culinary skills improvement of learning outcomes making steamed brownies in children with mild mental retardation using explicit instruction learning model. The research was conducted on the students of class XII SMALB-C Kembar Karya I, East Jakarta, with 2 student from September to October 2012. This study used Classroom Action Research with 2 cycles where each cycle consisted of 2 meetings. The research success was analyzed individually, one aspect for each student as the development of children with mental retardation can not be compared to other children, but the progress on himself. The results showed that using explicit instruction learning model increases learning outcomes in culinary skills of making steamed brownies for the students with mild mental retardation.

Keywords: children with mild mental retardation, culinary skills, steamed brownies, explicit instruction.

\section{PENDAHULUAN}

Anak berkebutuhan khusus adalah anak yang memiliki keterbatasan pada dirinya. Salah satu keterbatasan tersebut adalah keterbatasan mental atau disebut tunagrahita. Kondisi ini menyebabkan individu yang bersangkutan mengalami hambatan dalam belajar dan melakukan berbagai fungsi dalam kehidupan serta penyesuaian diri. Berbagai upaya dilakukan untuk membekali anak tunagrahita agar mereka bisa bersosialisasi dalam kehidupan yang lebih layak di masyarakat.

SLB Kembar Karya I merupakan salah satu sekolah yang melayani pendidikan bagi anak-anak yang memiliki kekurangan, salah satunya bagi anak tunagrahita ringan. Jenjang pendidikan yang ada untuk anak tunagrahita ringan di SLB Kembar Karya I, yaitu TKLB, SDLB, SMPLB, dan SMALB. Setelah selesai mengikuti pendidikan pada jenjang SMALB-C, biasanya anak tunagrahita ringan jarang sekali untuk meneruskan pendidikan ke jenjang pendidikan yang lebih tinggi. Hal ini dikarenakan sangat sedikit sekali sekolah untuk anak tunagrahita dan faktor biaya yang sangat besar. Selain itu, anak tunagrahita ringan juga mengalami kesulitan dalam mencari pekerjaan, dikarenakan kekurangan yang dimilikinya.

Sekolah Luar Biasa merupakan tempat bagi para anak tunagrahita ringan mengembangkan keterampilannya. Pelajaran yang diberikan lebih difokuskan pada keterampilan yang diharapkan dapat memberikan bekal untuk berwirausaha bagi anak tunagrahita ringan. Keterampilan yang diberikan di antaranya tata boga, tata busana, pertukangan, dan perbengkelan. Namun kenyataan yang ada pada Sekolah Luar Biasa Kembar Karya I, anak tunagrahita ringan belum menguasai keterampilan yang diberikan. 
Keterampilan memasak yang diberikan pada pelajaran tata boga difokuskan pada pembuatan kue dan makanan ringan. Sedangkan pengelolaan wirausaha difokuskan pada penjualan kue dan makanan. Dalam penelitian ini dikhususkan pada pembuatan brownis kukus, karena brownis kukus merupakan kue disukai oleh kalangan tua dan muda. Cokelatnya yang dapat membangkitkan selera, dan rasanya yang lembut memiliki ciri khas tersendiri. Selain itu pembuatannya sangat mudah, bahanbahannya mudah didapatkan, dan peralatannya pun biasanya sudah ada di dapur keluarga.

Selama ini peneliti melihat di kelas XII SMALB Kembar Karya I pada mata pelajaran tata boga belum mencapai hasil yang maksimal. Hal ini disebabkan karena anak tunagrahita ringan kesulitan dalam memahami konsep perintah, sehingga pada mata pelajaran tata boga perlu diterapkan model pembelajaran eksplisit. Model pembelajaran eksplisit merupakan model pembelajaran yang mengarah pada prosedural. Model pembelajaran ini digunakan untuk menyampaikan pelajaran yang ditransformasikan langsung oleh guru kepada peserta didik. Dengan menggunakan model pembelajaran eksplisit, penyampaian proses keterampilan diharapkan dapat lebih mudah diberikan oleh guru. Karakteristik anak tunagrahita ringan cenderung mengalami kesulitan dalam menerima, memproses, dan mengingat berbagai stimulus yang diterima. Kesulitan tersebut dapat ditanggulangi dengan memberikan proses belajar secara langsung dan berulang-ulang. Proses belajar tersebut akan membantu mereka untuk dapat melakukan berbagai stimulus yang diberikan.

Dalam kegiatan memasak, peserta didik masih perlu bimbingan guru. Hal ini karena kurangnya latihan yang lebih mandiri. Dengan menerapkan model pembelajaran eksplisit yang dilakukan secara berulang-ulang diharapkan anak tunagrahita ringan dapat mengerjakan sesuatu secara mandiri, sehingga peserta didik mampu berwirausaha dengan menjual hasil produk buatan sediri. Dengan demikian, penggunaan model pembelajaran eksplisit diharapkan anak tunagrahita ringan dapat memahami perintah yang ada dalam kehidupan sehari-hari, begitu juga dalam praktik pembuatan brownis kukus dan penjualannya yang diajarkan di sekolah.

Berdasarkan kondisi pada kelas XII SMALB-C Kembar Karya I, penulis merasa perlu meningkatkan hasil belajar keterampilan tata boga materi pembuatan brownis kukus pada anak tunagrahita ringan. Meningkatkan keterampilan dan pengelolaan wirausaha dikhususkan pada pembuatan brownis kukus dengan menggunakan model pembelajaran eksplisit pada anak tunagrahita ringan kelas XII SMALB-C Kembar Karya I. Model pembelajaran eksplisit diberikan agar peserta didik mampu memasak kue tanpa bimbingan guru. Implementasinya diharapkan anak tunagrahita ringan dapat melakukan pengelolaan wirausaha terbimbing.

Berdasarkan latar belakang tersebut, maka dalam penelitian ini dirumuskan masalah sebagai berikut: "Bagaimanakah meningkatkan hasil belajar keterampilan tata boga materi pembuatan brownis kukus pada anak tunagrahita ringan kelas XII SMALB Kembar Karya I melalui model pembelajaran eksplisit?"

Penelitian ini menggunakan beberapa kajian teori yang melandasinya, di antaranya: (a) tunagrahita, (b) model pembelajaran eksplisit, dan (c) keterampilan tata boga. Ketiga kajian teori tersebut akan diuraikan sebagai berikut.

A. Tunagrahita

Tunagrahita merupakan istilah yang digunakan untuk menyebut anak yang mempunyai kemampuan intelektual di bawah rata-rata. Retardasi mental atau dikenal dengan istilah disabilitas inteligensia (di Indonesia dikenal dengan nama tunagrahita) adalah individu yang mengalami keterbatasan mental (Jamaris, 2010 : 269). Anak tunagrahita dikenal juga dengan istilah keterbelakangan mental karena keterbatasan kecerdasannya mengakibatkan dirinya sukar untuk mengikuti program di sekolah biasa secara klasikal. Pada masa awal perkembangan, hampir tidak ada perbedaan antara anak-anak tunagrahita dengan anak yang memiliki kecerdasan rata-rata. Akan tetapi, semakin lama perbedaan pola perkembangan antara anak tunagrahita dengan anak normal semakin terlihat jelas.

Definisi retardasi mental dikemukakan oleh The American Association on Mental Retardation, pada tahun 1992, yaitu "Mental retardation refers to substantial limitations in present functioning. It is characterized by significantly subaverage intellectual functioning, existing concurrently with related limitation in two or more of the following applicable adaptive skills areas: communication. Self care, home living, social skills, community use, self-direction, health and safety, functional academics, leisure and work. Mental retardation manifests before age 18" (Jamaris, 2010).

Tunagrahita atau keterbelakangan mental merupakan kondisi di mana perkembangan kecerdasan individu yang mengalami hambatan sehingga tidak mencapai tahap perkembangan yang optimal. Ada beberapa karakteristik umum tunagrahita yang dapat 
dipelajari (Somantri, 2007 : 105).

Pertama, keterbatasan inteligensi. Inteligensi merupakan fungsi yang kompleks yang dapat diartikan sebagai kemampuan untuk mempelajari informasi dan keterampilan menyesuaikan diri dengan masalah-masalah dan situasi-situasi kehidupan baru, belajar dari pengalaman masa lalu, berpikir abstrak, kreatif, dapat menilai secara kritis, menghindari kesalahan-kesalahan, mengatasi kesulitan-kesulitan, serta kemampuan untuk merencanakan masa depan. Anak Tunagrahita memiliki kekurangan dalam semua hal tersebut.

Kedua, keterbatasan sosial. Selain keterbatasan inteligensi, anak Tunagrahita juga memiliki kesulitan dalam mengurus diri sendiri dalam masyarakat. Anak tunagrahita cenderung berteman dengan anak yang lebih muda usianya, ketergantungan dengan orang tua sangat besar, tidak mampu memikul tanggung jawab sosial dengan bijaksana, sehingga mereka harus selalu dibimbing dan diawasi.

Ketiga, keterbatasan fungsi-fungsi mental lainnya. Anak tunagrahita memerlukan waktu lebih lama untuk menyelesaikan reaksi pada situasi yang baru dikenalnya. Anak tunagrahita tidak dapat menghadapi sesuatu kegiatan atau tugas dalam jangka waktu yang lama. Anak tunagrahita memiliki keterbatasan juga dalam penguasaan bahasa. Selain itu, anak tunagrahita kurang mampu untuk mempertimbangkan sesuatu, membedakan antara yang baik dan buruk, serta membedakan yang benar dan salah.

Pengelompokan pada umumnya didasarkan pada taraf inteligensi. Kemampuan inteligensi anak tunagrahita kebanyakan diukur dengan tes Standford Binet dan Skala Weschler (WISC). Tuna grahita dibagi ke dalam tiga kelompok. Pertama, tunagrahita ringan disebut juga moron atau debil. Kelompok ini memiliki IQ antara 68-52 menurut Skala Binet, sedangkan menurut Skala Weschler (WISC) memiliki IQ 69-55. Mereka masih dapat belajar membaca, menulis, dan berhitung sederhana. Dengan bimbingan dan pendidikan yang baik, anak tunagrahita ringan akan dapat memperoleh penghasilan untuk dirinya sendiri.

Kedua, tunagrahita sedang disebut juga imbesil. Kelompok ini memiliki IQ 51-36 pada Skala Binet dan 54-40 menurut Skala Weschler (WISC). Anak tunagrahita sedang bisa mencapai perkembangan mental age sampai kurang lebih 7 tahun. Mereka dapat dididik untuk mengurus dan melindungi diri sendiri dari bahaya seperti menghindari kebakaran, berjalan di jalan raya, berlindung dari hujan, dan sebagainya.

Ketiga, tunagrahita berat. Kelompok anak tunagrahita berat sering disebut idiot. Kelompok ini dapat dibedakan lagi antara anak tunagrahita berat dan sangat berat. Tunagrahita berat (sereve) memiliki IQ antara 32-20 menurut Skala Binet dan antara 39-25 menurut Skala Weschler (WISC). Tunagrahita sangat berat (profound) memiliki IQ di bawah 19 menurut Skala Binet dan IQ di bawah 24 menurut Skala Weschler (WISC). Kemampuan mental maksimal yang dapat dicapai kurang dari tiga tahun. Anak tunagrahita berat memerlukan bantuan perawatan secara total dalam hal berpakaian, mandi, makan, dan lain-lain. Bahkan mereka memerlukan perlindungan dari bahaya sepanjang hidupnya (Somantri, 2007 : 106). B. Model Pembelajaran Eksplisit

Untuk membelajarkan peserta didik yang sesuai dengan gaya belajar mereka sehingga tujuan pembelajaran dapat dicapai dengan optimal, maka ada berbagai model pembelajaran yang perlu diterapkan dalam kegiatan pembelajaran. Dalam praktiknya, harus ingat bahwa tidak ada model pembelajaran yang paling tepat untuk segala situasi dan kondisi. Oleh karena itu, dalam memilih model pembelajaran yang tepat haruslah memperhatikan kondisi peserta didik, sifat materi bahan ajar, fasilitas media yang tersedia, dan kondisi guru itu sendiri. Dalam kaitan ini, penulis menyajikan model pembelajaran eksplisit.

Setiap model pembelajaran mengarahkan kita ke dalam mendesain pembelajaran untuk membantu peserta didik sedemikian rupa sehingga tujuan pembelajaran tercapai (Trianto, 2010: 22). Merujuk pada hal ini, perkembangan model pembelajaran terus mengalami perubahan dari model tradisional menuju model yang lebih modern. Model pembelajaran berfungsi untuk memberikan situasi pembelajaran yang tersusun rapi untuk memberikan suatu aktivitas kepada peserta didik guna mencapai tujuan pembelajaran.

Model explicit instruction merupakan suatu pendekatan pembelajaran yang dapat membantu peserta didik dalam mempelajari keterampilan dasar dan memperoleh informasi yang dapat diajarkan selangkah demi selangkah. Pendekatan pembelajaran ini sering disebut model pembelajaran langsung. Model explicit instruction adalah salah satu pendekatan pembelajaran yang dirancang khusus untuk menunjang proses belajar peserta didik yang berkaitan dengan pengetahuan deklaratif dan prosedural yang terstruktur dengan baik yang dapat diajarkan dengan pola kegiatan yang bertahap, selangkah demi selangkah (Arends dalam Trianto, $2010: 41)$.

Model explicit instruction memiliki kelebihan, 
model explicit instruction diantaranya (a) guru dapat mengendalikan isi materi dan urutan informasi yang diterima oleh peserta didik sehingga dapat mempertahankan fokus mengenai apa yang harus dicapai oleh peserta didik, (b) dapat diterapkan secara efektif dalam kelas yang besar maupun kecil, (c) dapat digunakan untuk menekankan poin-poin penting atau kesulitan-kesulitan yang mungkin dihadapi peserta didik sehingga hal-hal tersebut dapat diungkapkan, (d) menjadi cara yang efektif untuk membelajarkan informasi dan pengetahuan faktual yang sangat terstruktur; (e) merupakan cara yang paling efektif untuk membelajarkan konsep dan keterampilan eksplisit kepada peserta didik yang berprestasi rendah, (f) menjadi cara untuk menyampaikan informasi yang banyak dalam waktu yang relatif singkat yang dapat diakses secara setara oleh seluruh peserta didik, dan (g) memungkinkan guru untuk menyampaikan ketertarikan pribadi mengenai mata pelajaran (melalui presentasi yang antusias) yang dapat merangsang ketertarikan dan antusiasme peserta didik.

Model pembelajaran langsung bersandar pada kemampuan peserta didik untuk mengasimilasikan informasi melalui kegiatan mendengarkan, mengamati, dan mencatat. Oleh karena itu, tidak semua peserta didik memiliki keterampilan dalam hal-hal tersebut, guru masih harus mengajarkannya kepada peserta didik.

Kedua, dalam model pembelajaran langsung, sulit untuk mengatasi perbedaan dalam hal kemampuan, pengetahuan awal, tingkat pembelajaran dan pemahaman, gaya belajar, atau ketertarikan peserta didik.

Ketiga, karena peserta didik hanya memiliki sedikit kesempatan untuk terlibat secara aktif, sulit bagi peserta didik untuk mengembangkan keterampilan sosial dan interpersonal mereka.

Keempat, karena guru memainkan peran pusat dalam model ini, kesuksesan strategi pembelajaran ini bergantung pada citra guru. Jika guru tidak tampak siap, berpengetahuan, percaya diri, antusias, dan terstruktur, peserta didik dapat menjadi bosan, teralihkan perhatiannya, dan pembelajaran mereka akan terhambat.

Kelima, terdapat beberapa bukti penelitian bahwa tingkat struktur dan kendali guru yang tinggi dalam kegiatan pembelajaran, yang menjadi karakteristik model pembelajaran langsung, dapat berdampak negatif terhadap kemampuan penyelesaian masalah, kemandirian, dan keingintahuan peserta didik.

C. Keterampilan Tata Boga

Keterampilan adalah kemampuan melakukan pola-pola tingkah laku yang kompleks dan tersusun rapih secara mulus dan sesuai dengan keadaan untuk mencapai hasil tertentu (Reber dalam Syah, 2009 : 119). Tata boga merupakan salah satu mata pelajaran untuk meningkatkan keterampilan peserta didik. Pelajaran yang diberikan terfokus pada pengelolaan, pembuatan, dan penyajian makanan.

Keterampilan yang diberikan pada pelajaran tata boga dengan menggunakan metode latihan dapat terbagi dua yaitu keterampilan intelektual dan keterampilan motorik. Keterampilan intelektual adalah keterampilan pengetahuan untuk melaksanakan atau menyelesaikan sesuatu secara pasif. Dalam pelajaran tata boga, keterampilan ini dapat meningkatkan pengetahuan peserta didik mengenai cara-cara pengelolaan, pembuatan, dan penyajian makanan. Sedangkan keterampilan motorik adalah keterampilan mengerjakan sesuatu secara aktif. Dalam pelajaran tata boga peserta didik mampu mengelola, membuat, dan menyajikan makanan.

\section{METODE PENELITIAN}

Penelitian ini menggunakan metode penelitian tindakan (action research). Penelitian ini dilakukan dengan pemberian siklus. Setiap siklus mempunyai empat kegiatan utama yaitu perencanaan, tindakan, pengamatan, dan refleksi. Kegunaan penelitian tindakan ini adalah untuk meningkatkan hasil belajar keterampilan tata boga materi pembuatan brownis kukus. Model pembelajaran yang digunakan adalah model explicit instruction dimana pembelajaran akan dilakukan secara langsung dan berulang-ulang.

Penelitian ini dilaksanakan di Sekolah Luar Biasa (SLB) Kembar Karya I Jakarta Timur. Observasi awal dilakukan pada bulan September 2012 dan penelitian dilakukan pada bulan September 2012 sampai Oktober 2012. Subjek dalam penelitian ini adalah peserta didik kelas XII SMALB Kembar Karya I semester I tahun pelajaran 2012/2013 dengan jumlah 2 orang yang terdiri dari 2 laki-laki.

Penelitian ini menganalisis cara meningkatkan hasil belajar keterampilan tata boga materi pembuatan brownis kukus pada anak tunagrahita ringan kelas XII SMALB Kembar Karya I melalui model pembelajaran explicit instruction. Instrumen pengumpulan data yang digunakan dalam penelitian tindakan ini yaitu observasi, catatan lapangan, wawancara dan dokumentasi penelitian. Pengambilan data dilakukan dengan cara mengamati kegiatan keterampilan tata boga materi pembuatan brownis kukus. Dalam penelitian ini dilaksanakan dua siklus setiap siklusnya terdapat 2 
kali pertemuan. Pada siklus pertama, peserta didik melakukan praktik pembuatan brownis kukus dengan bantuan guru dan pada siklus kedua, peserta didik melakukannya dengan sendiri. Upaya meningkatkan hasil belajar keterampilan tata boga materi pembuatan brownis kukus dilakukan pada semester I tahun ajaran 2012/2013 yang dilaksanakan setiap seminggu sekali di ruangan latihan.

Teknik analisis data yang dilakukan adalah analisis data kualitatif dan kuantitatif. Analisis data kualitatif dilakukan dengan mengumpulkan data yang diperoleh dari instrumen penelitian. Data catatan lapangan dan wawancara akan dibandingkan dengan data observasi yang akan diamati melalui pembuatan grafik. Kemudian akan diambil kesimpulan dari persamaan dan perbedaan data. Analisis kuantitatif dilakukan untuk melihat perbedaan penilaian hasil belajar keterampilan tata boga materi pembuatan brownis kukus melalui metode explicit instruction antara pra tindakan maupun hasil intervensi siklus, berdasarkan data yang diperoleh di lapangan untuk mengetahui rata-rata perbedaan nilai sebelum dan sesudah dilakukan intervensi tindakan berupa tahapan dalam kegiatan keterampilan tata boga materi pembuatan brownis kukus. Keberhasilan penelitian disimpulkan dengan menggunakan analisis persentase dinyatakan berhasil jika persentase penilaian hasil belajar keterampilan tata boga materi pembuatan brownis kukus $>70 \%$, ini berarti hasil belajar keterampilan tata boga materi pembuatan brownis kukus pada anak usia dini berkebutuhan khusus dengan tingkat tunagrahita ringan dapat meningkat setelah dilakukannya penelitian. Penetapan keberhasilan persentase ini dilandaskan pada kemampuan yang dimiliki anak dengan tingkat tunagrahita ringan cenderung mengalami kesulitan dalam menerima, memproses, dan mengingat berbagai stimulus yang diterima.

\section{HASIL DAN PEMBAHASAN}

\section{Hasil Penelitian}

Sebelum dilakukannya siklus, peneliti mengadakan obeservasi mengenai kondisi kemampuan peserta didik kepada kolaborator. Hasil observasi awal adalah pada saat peserta didik berada di kelas XI, sudah diberikan pelajaran pembuatan brownis kukus maka tes awal yang diberikan yaitu berupa praktikum pembuatan brownis kukus. Pada tes awal yang diberikan hasil belajar keterampilan tata boga membuat brownis kukus belum dimiliki secara maksimal oleh peserta didik.

Pada siklus I, peneliti bersama kolaborator menerapkan kegiatan sesuai dengan rencana pembelajaran yang telah disusun. Ba merupakan anak yang aktif dalam mengikuti kegiatan pembelajaran. Ia senang sekali mengajukan pertanyaan, namun kadang kala sangat senang bercanda, sehingga guru harus selalu mengingatkannya. Ba mengalami peningkatan hasil belajar keterampilan tata boga materi pembuatan brownis kukus sebesar $9 \%$. Sudah terdapat peningkatan, tetapi peningkatan yang dialami Ba belum maksimal dan belum mencapai target sebesar $70 \%$.

Kemudian, Ta juga peserta didik yang sering ditemui tidak fokus, ia sering termenung dan tidak memperhatikan guru. Ta jarang mengajukan pertanyaan, namun ia bisa menjawab pertanyaan yang diberikan guru. Ta mengalami peningkatan hasil belajar keterampilan tata boga materi pembuatan brownis kukus sebesar $11,5 \%$. Sudah terdapat peningkatan, tetapi peningkatan yang dialami Ta belum maksimal dan belum mencapai target sebesar $70 \%$. Berdasarkan hasil pada pengamatan siklus I, peneliti dan kolaborator melihat peningkatan peserta didik masih kurang optimal, karena dalam pembuatan brownis kukus, peserta didik masih mendapatkan bimbingan guru. Berdasarkan hal tersebut, latihan secara mandiri akan dilakukan pada siklus II.

Pada siklus II permasalahan yang timbul adalah peserta didik kelas XII SMALB-C dapat membuat brownis kukus, namun masih dalam bimbingan guru. Keterampilan peserta didik pada siklus I masih kurang optimal sehingga pada siklus II, tingkat latihan selanjutnya yang diberikan adalah peserta didik mempraktikan sendiri pembuatan brownis kukus. Guru selalu menegur Ba disaat ia bercanda sehingga Ba sudah jarang bercanda dan mampu mengikuti kegiatan pembelajaran dengan baik. Ba mengalami peningkatan hasil belajar keterampilan tata boga materi pembuatan brownis kukus sebesar 15,3\%. Peningkatan yang dialami Ba sudah maksimal dan sudah mencapai target melebihi 70\%. Guru sering mendampingi Ba dan selalu mengajukan pertanyaan sehingga Ba menjadi fokus dan dapat mengikuti kegiatan pembelajaran dengan baik. Ba mengalami peningkatan hasil belajar keterampilan tata boga materi pembuatan brownis kukus sebesar 15,4 \%. Peningkatan yang dialami Ba sudah maksimal dan sudah mencapai target melebihi $70 \%$. Berdasarkan hasil pada pengamatan siklus II, peneliti dan kolaborator melihat peningkatan peserta didik yang sudah optimal, karena dalam pembuatan brownis kukus, peserta didik dapat mempraktikan secara mandiri.

Perspektif Ilmu Pendidikan - Vol. 28 No. 1 April 2014 


\section{Pembahasan}

Berdasarkan hasil perhitungan persentase memperlihatkan peningkatan hasil belajar keterampilan tata boga materi pembuatan brownis kukus. Dengan demikian model pembelajaran explicit instruction mempunyai pengaruh dalam meningkatkan hasil belajar keterampilan tata boga materi pembuatan brownis kukus pada anak tunagrahita ringan.

Keberhasilan penelitian disimpulkan dengan menggunakan hasil persentase pada siklus terakhir dimana persentase keterampilan peserta didik melebihi $70 \%$, ini berarti hasil belajar keterampilan tata boga materi pembuatan brownis kukus pada anak tunagrahita ringan dapat meningkat setelah menggunakan model pembelajaran explicit instruction.

Berdasarkan hasil penilaian dari siklus I, terdapat peningkatan hasil belajar keterampilan tata boga materi pembuatan brownis kukus. Dari analisis persentase terdapat peningkatan yaitu Ba sebesar 9\% dan Ta sebesar 11.5\%. Dengan demikian terdapat peningkatan hasil belajar keterampilan tata boga materi pembuatan brownis kukus tetapi belum mencapai lebih dari $70 \%$.

Sedangkan pada hasil penilaian dari siklus II, terdapat peningkatan hasil belajar keterampilan tata boga materi pembuatan brownis kukus. Berdasarkan perhitungan persentase, hasil belajar keterampilan tata boga materi pembuatan brownis kukus pada anak tunagrahita ringan sudah lebih dari 70\%. Dengan demikian, peningkatan hasil belajar keterampilan tata boga materi pembuatan brownis kukus sudah maksimal.

Berdasarkan pembahasan siklus I dan II maka dapat disintesiskan temuan penelitian sebagai berikut: 1. Kemampuan Motorik Anak Tunagrahita yang Rendah

Dalam melakukan kegiatan praktikum, Ba melakukan kegiatan dengan ragu dan Ta melakukannya dengan kurang hati-hati, hal ini dikarenakan kemampuan motorik mereka yang kurang sehingga mengalami kesulitan dalam melakukan kegiatan psikomotor. Kemampuan motorik yang kurang oleh karena banyak kerusakan sel otak, anak tunagrahita mengalami gangguan motorik. Ia tidak dapat bergerak dengan tepat, kaku, dan koordinasi motorik tidak baik. Kekurangan ini dapat terlihat pada cara berjalan, lari, lompat, melempar, menulis, memotong dan pekerjaan lainnya (Astati 2011).

2. Ba peserta didik yang suka mengganggu temannya

Ba anak yang sangat senang sekali bercanda sehingga ia sangat senang mengganggu orang di sekelilingnya sehingga perhatiannya mudah sekali teralihkan. Perhatian anak tunagrahita hanya berlangsung sebentar. Ia mudah merasa lelah, bosan dan akhirnya mengalihkan perhatiannya ke hal-hal yang lain. Ia mudah terangsang oleh sesuatu yang ada disekitarnya sehingga mengganggu anak lain (Astati 2011).

3. Pembelajaran anak tunagrahita harus menggunakan prinsip keperagaan, pengulangan dan individualisasi

Anak tunagrahita mengalami hambatan dalam menerima informasi. Mereka akan cenderung diam saja jika hanya dinstruksikan dan diperagakan sekali. Mereka butuh pengulangan instruksi dan memperagakan secara jelas. Selain itu, pembelajaran anak tunagrahita harus dilakukan secara individual, hal ini dikarenakan peserta didik mempunyai kemampuan yang berbeda-beda (Astati 2011).

a. Prinsip keperagaan

Prinsip ini digunakan dalam mengajar anak tunagrahita mengingat keterbatasan anak tunagrahita dalam berpikir abstrak.

b. Prinsip pengulangan

Berhubung anak tunagrahita cepat lupa mengenai apa yang dipelajarinya maka dalam mengajar mereka membutuhkan pengulangan-pengulangan.

c. Prinsip Individualisasi

Prinsip ini menekankan perhatian pada perbedaan individual anak tunagrahita. Anak tunagrahita belajar sesuai dengan iramanya sendiri.

4. Guru tunagrahita mempunyai karakteristik yang berbeda

Selama penelitian berlangsung, peneliti dan kolaborator menciptakan hubungan sosio-emosional yang baik terhadap peserta didik. Peserta didik yang mudah bosan dan sulit diatur harus selalu diarahkan dan dibimbing. Hal ini membuat guru mengeluarkan tenaga ekstra untuk menghadapi mereka. Guru tunagrahita harus mempunyai jiwa penyabar dalam menghadapi anak tunagrahita. Karakteristik guru yang dapat menunjang terciptanya hubungan sosio-emosional adalah disukai siswa, memiliki persepsi yang realistik tentang dirinya dan siswanya, akrab dengan siswa dalam batasan hubungan guru-siswa, bersikap positif terhadap pernyataan siswa, serta sabar, teguh, dan tegas (Sri Widati 2011).

\section{PENUTUP}

\section{Kesimpulan}

Berdasarkan hasil penelitian, dapat terlihat adanya peningkatan hasil belajar keterampilan tata boga materi pembuatan brownis kukus pada peserta didik kelas XII SMALB-C Kembar Karya I. Hal ini dapat terlihat dari pengamatan dan penilaian pada penelitian. Pada siklus I terdapat peningkatan hasil 
belajar keterampilan tata boga materi pembuatan brownis kukus, namun belum melebihi 70\%. Kemudian pada siklus II terdapat peningkatan hasil belajar keterampilan tata boga materi pembuatan brownis kukus yang sudah melebihi $70 \%$.

Dengan demikian, dapat dikatakan bahwa penelitian ini berhasil karena adanya peningkatan hasil belajar keterampilan tata boga materi pembuatan brownis kukus pada anak tunagrahita ringan kelas XII SMALB-C Kembar Karya I. Peningkatan ini disebabkan oleh penggunaan model pembelajaran explicit instruction yang membuat peserta didik mengetahui langkah-langkah membuat brownis kukus dan pembelajaran yang berulang-ulang sehingga peserta didik mampu membuat brownis kukus secara mandiri.

\section{Saran}

Berkaitan dengan hasil penelitian, peneliti mengemukakan saran sebagai berikut:

Pertama, sekolah. Kegiatan pembelajaran hendaknya dilaksanakan secara berkesinambungan, terutama pada mata pelajaran yang memberikan keterampilan pada peserta didik. Selain itu, sekolah hendaknya mendukung dan memberikan kebebasan pada guru untuk berkreasi, sehingga tujuan pembelajaran dapat tercapai. Kedua, guru. Guru hendaknya mampu mengembangkan kemampuan dalam mengajar, agar tujuan pembelajaran dapat tercapai. Selain itu, perhatian yang sangat ekstra di dalam kelas juga sangat dibutuhkan. Komunikasi dengan orang tua murid juga sangat perlu, sehingga orang tua dapat mendukung keterampilan peserta didik. Ketiga, orang tua. Orang tua hendaknya mendukung hasil pembelajaran yang telah diperoleh peserta didik. Keempat, penelitian lanjutan. Untuk penelitian lanjutan, efektifitas model pembelajaran explicit instruction dapat diimplementasikan dalam peningkatan keterampilan pada mata pelajaran lainnya.

\section{DAFTAR PUSTAKA}

Astati. (2011). Bina diri untuk anak tunagrahita. Bandung: Amanah Offset

Astati. (2011). Pendidikan anak tunagrahita. Bandung: Amanah Offset

Jamaris, M. (2010). Orientasi baru dalam psikologi pendidikan. Jakarta: Yayasan Panamas Murni

Mertler, C.A. (2009). Action research. California: SAGE Publications

Qurtubi, A. (2009). Teknologi dan media pendidikan. Jakarta: Bintang Harapan Sejahtera

Riyadi, N. (2011). Tunagrahita. Diakses dari http:// edukasi.kompasiana.com/2011/09/24/ Tunagrahita/ pada tanggal 10 Juli 2012.

Sagala, S. (2009). Konsep dan makna pembelajaran. Bandung: Alfa Beta

Somantri, S . (2007). Psikologi anak luar biasa. Jakarta: Refika Aditama

Suprijono, A. (2011). Cooperative learning: Teori dan aplikasi PAIKEM. Yogyakarta: Pustaka Belajar

Syah, M. (2009). Psikologi pendidikan dengan pendekatan baru. Bandung: Remaja Rosda Karya

Trianto. (2010). Mendesain model pembelajaran inovatifprogresif. Jakarta: Kencana

Widati, S. (2011). Pembelajaran kreatif dalam pendidikan anak berkebutuhan khusus. Bandung: Amanah Offset. 